\title{
Insulin-like growth factor I (IGF-I), IGF-II and type-I IGF receptor gene expression in the ovary of the laying hen
}

\author{
D. G. Armstrong and C. O. Hogg \\ Division of Development and Reproduction, Roslin Institute (Edinburgh), Roslin, Midlothian, EH25 9PS, \\ UK
}

\begin{abstract}
Expression of genes encoding insulin-like growth factor I (IGF-I), insulin-like growth factor II (IGF-II) and type I insulin-like growth factor receptor (IGFr) was measured in theca and granulosa cells from the ovary of the laying hen, using an RNase protection assay. Expression of genes encoding IGF-I and -II was confined to theca tissue and expression was not detected in granulosa cells. In contrast, expression of genes encoding IGFr in granulosa cells was significantly greater than that in theca tissue. The 98 base IGF-II probe was similar to a region of the second coding exon of chicken IGF-II and produced multiple RNase-protected RNA hybrids. Theca RNA from follicles at all stages of development produced RNase-protected hybrids of size 98,96 and 90 bases; however, an additional band (66 bases) was also observed in theca RNA from small yellow follicles. The stage of follicular development during which maximum amounts of the 66 base RNase-protected fragment was detected correlates with the stage at which small follicles are selected for recruitment into the follicular hierarchy. The results provide evidence for the involvement of IGFs in the intraovarian control of ovarian function in a non-mammalian species, and highlight the importance of IGF-II in this process.
\end{abstract}

\section{Introduction}

Insulin-like growth factors I and II (IGF-I and IGF-II) are part of a family of peptides, structurally related to proinsulin, that stimulate cell division and differentiation in vitro (Daughaday and Rotwein, 1989; Rotwein, 1991). Their effects are mediated by the type-I IGF receptor (IGFr) that shows a high degree of similarity to the insulin receptor (Rechler and Nissley, 1985).

There is an increasing body of evidence indicating a role for IGFs in the control of ovarian function. The ovary is a major site of hormonally regulated production of IGF-I and IGF-II (Adashi and Roban, 1992; Adashi et al., 1992; Giudice, 1992) and IGF-I has been shown to potentiate the action of gonadotrophins on granulosa and theca interstitial cells in vitro (Hsu and Hammond, 1987; Hutchinson et al., 1988; Mondschein et al., 1989). For example, in rats, IGF-I increases FSH stimulation of progesterone production, the induction of aromatase activity and the acquisition of $\mathrm{LH}$ receptors in granulosa cells (Adashi et al., 1985). However, the precise function for IGFs in the intact, developing follicle remains to be clarified. In Laron-type dwarfism, a condition arising in humans from IGF-I deficiency (Laron ef al., 1966), normal follicular development has been described (Dor et al., 1992). Similarly, the reproductive performance of chickens containing the sex-linked dwarfing gene, a condition arising from an inactive $\mathrm{GH}$ receptor and resulting in greatly diminished IGF-I production, is improved over that of their normal controls (Decuypere et al., 1991). Nevertheless, an absolute requirement for IGF-I in normal ovarian function has been demonstrated using gene targeting

Received 9 June 1995. techniques. Growth retarded, adult, female mice, in which the IGF-I gene was disrupted (Liu et al., 1993) exhibited a marked reduction in ovarian size and were infertile (Baker et al., 1993).

Evidence is accumulating from studies of a number of mammals, indicating that expression of the genes encoding IGF-I and IGF-II is developmentally regulated in a tissue- and species-specific manner. In humans, expression of the gene encoding IGF-II has been localized to granulosa cells of the dominant follicle and theca interstitial cells of small antral follicles, whereas expression of the gene encoding IGF-I appears to be confined solely to the theca interstitial cells (Hernandez et al., 1992; El-Roeiy et al., 1993). However, in rats, expression of the gene encoding IGF-I is confined to granulosa cells and the theca interstitial cells express the gene encoding IGF-II (Oliver et al., 1989; Hernandez et al., 1990).

Little is known about the IGF-ovarian system in nonmammals. However, one study demonstrated expression of the gene encoding IGF-I in both granulosa cells and theca tissue from preovulatory follicles of laying hens (Roberts et al., 1994). IGF-I interacts with LH in stimulating $\left[{ }^{3} \mathrm{H}\right]$ thymidine incorporation into DNA and progesterone production by granulosa cells (Roberts et al., 1994; Peddie et al., 1993; Onagbesan and Peddie, 1995). A single high-affinity binding site for IGF-I was detected on granulosa and theca tissue that displayed the characteristics of the type-I IGF receptor.

The present study extends previous work by describing the temporal and spatial expression of genes encoding IGF-I, IGF-II and IGFr in the developing ovarian follicles from laying hens. The avian ovary is particularly suited to such studies. 
It contains a hierarchy of large preovulatory follicles $(>8 \mathrm{~mm}$ ) which allows a mature ovum to ovulate on successive days throughout a laying sequence, and granulosa and theca tissue are easily collected from these follicles at accurately defined stages of development (Etches, 1990). The hierarchy is maintained by recruitment of small yellow follicles $(<6 \mathrm{~mm})$ into the hierarchy, one follicle being recruited per day throughout a laying sequence.

The results describe a unique developmental pattern for the expression of the genes encoding IGF-I, IGF-II and IGFr and provide further evidence of a role for IGFs in the autocrine and paracrine control of ovarian function in non-mammals. The importance of IGF-II as an intraovarian regulator of folliculogenesis is highlighted and a role for variant forms of this peptide in the mechanism whereby small folicles are selected for recruitment into the final rapid phase of follicular growth is discussed.

\section{Materials and Methods}

\section{Animals}

A flock of commercial, brown egg laying hens (Hissex; 30-40 weeks old) were housed individually under a lighting regimen of $14 \mathrm{~h}$ light: $10 \mathrm{~h}$ dark, with food and water freely available. Birds were selected in the middle of a laying sequence and killed $3 \mathrm{~h}$ after or 2-4 h before an expected ovulation. The predicted time of the expected ovulation was confirmed post mortem by the presence of an ovum in the magnum region of the oviduct ( $3 \mathrm{~h}$ after an ovulation) or by the presence of a hard shelled egg in the shell gland $(2-4 \mathrm{~h}$ before an ovulation). The birds were killed by cervical dislocation and the ovaries were placed in ice cold saline until further dissection.

\section{Tissue collection and extraction of RNA}

Theca tissue was collected from the largest (F1), third largest (F3) and fifth largest (F5) preovulatory follicles and from 10-15 small, yellow, nonatretic follicles $(2-6 \mathrm{~mm}$ in diameter). Granulosa tissue was collected from the large preovulatory follicles. In a further experiment, the population of small yellow follicles was divided into three groups: $4-6 \mathrm{~mm}, 2-4 \mathrm{~mm}$ and I-2 $\mathrm{mm}$ in diameter. An additional group of atretic follicles, recognized by the presence of haemorrhages on their surface (Gilbert et al., 1983), were also collected. Theca tissue was isolated from these follicles as described by Armstrong (1994). All tissues were snap frozen in liquid nitrogen and stored at $-70^{\circ} \mathrm{C}$. Total RNA was extracted using guanidine thiocynate and phenol. The amount of RNA (mean (SEM); $n=4$ ) isolated from theca preparations from F1, F3, F5 and small (2-6 mm in diameter) follicles and granulosa from $\mathrm{F} 1$ granulosa cell preparations was $1530(80.3) \mu g, 1297(75.7) \mu g, 728$ (75.7) $\mu \mathrm{g}$, 1041 (215) $\mu \mathrm{g}$ and $175(20.6) \mu \mathrm{g}$, respectively. The ratio of absorbance at $260 \mathrm{~nm}$ to absorbance at $280 \mathrm{~nm}$ was $1.86(0.02)$ mean (SEM; $n=24$ ).

\section{RNA probes}

The ${ }^{32} \mathrm{P}$-labelled chicken IGFr probe was prepared as described by Armstrong and Hogg (1992). The IGF-I riboprobe was prepared from a plasmid containing a 224 base pair fragment of a chicken CDNA clone encoding IGF-I (Fawcett and Bulfield, 1990). The fragment, corresponding to positions 554-770 of the CDNA encoding IGF-I, was cloned into the SmaI site of pBS $( \pm)$ (Stratagene Ltd, Cambridge, UK) (J. M. Boswell, unpublished). The plasmid was linearized with BamHI and ${ }^{32}$ P-labelled antisense chicken IGF-I RNA transcripts were generated using T7 DNA-dependent RNA polymerase using the same conditions as described for the receptor probe. The IGF-II probe was prepared by reverse transcriptase-PCR using a custom made upstream primer $5^{\prime}$-TGTGGAGGAGTGCTGCTTTC-3' and downstream primer 5'-GGGAGGTGGCGGAGAGGTCA-3' (Oswel DNA, Edinburgh) using the method described by Armstrong and Hogg (1992). The primers correspond to positions 351-371 and 429-449, respectively, of a cDNA clone encoding IGF-II described by Taylor et al. (1991). RNA (1 $\mu$ g) from F1 theca was used as a template for the reverse transcriptase reaction. The amplified fragment was cloned into pCRII using a PCR cloning kit (Invitrogen; R\&D Systems Ltd, Abingdon), according to the manufacturer's instructions. The presence of the correct insert and its orientation within the plasmid was confirmed by DNA sequencing. The resulting plasmid was linearized with SpeI and ${ }^{32}$ P-labelled antisense RNA transcripts encoding IGF-II were generated using T7 DNA-dependent RNA polymerase. The conditions were as for the previous probes except that no unlabelled UTP was added to the labelling mixture. The RNA transcript contained 200 bases, 102 of which corresponded to the polycloning site of pCRII. A human $18 \mathrm{~S}$ ribosomal RNA probe was prepared by transcription in vitro using the pT7 RNA antisense control template (AMS Biotechnology UK Ltd, Witney). The labelling mixture for this probe was the same as for the IGF-I and IGFr probes, except that it contained $25 \mu \mathrm{Ci}\left[{ }^{32} \mathrm{P}\right] \mathrm{UTP}$ adjusted to $100 \mu \mathrm{mol} \mathrm{l}^{-1}$ with unlabelled UTP. The specific activity of the IGF-I and IGFr probes ranged from $2-5 \times 10^{8}$ d.p.m. $\mu \mathrm{g}^{-1}$; the IGF-II probe ranged from $1-3 \times 10^{9}$ d.p.m. $\mu g^{-1}$ and the $18 \mathrm{~S}$ ribosomal RNA probe was used at specific activity of $2-4 \times 10^{6}$ d.p.m. $\mu g^{-1}$

\section{RNase protection assay}

${ }^{32}$ P-labelled probes (50000-100000 d.p.m.) were added to the RNA samples $(5-50 \mu \mathrm{g})$ and precipitated in ethanol. The samples were then resuspended in $40 \mu$ l Pipes buffer $\left(0.025 \mathrm{~mol} \mathrm{l}^{-1}, \mathrm{pH} 6.8\right)$ containing $\mathrm{NaCl}\left(0.4 \mathrm{~mol} \mathrm{l}^{-1}\right)$, EDTA $\left(1.0 \mathrm{mmol} \mathrm{l}^{-1}\right)$ and formamide $(50 \%, \mathrm{v} / \mathrm{v})$. The concentration of labelled probes ranged from $2-6 \mathrm{ng} \mathrm{ml}^{-1}$ (IGF-I and IGFr probes), $0.1-0.3 \mathrm{ng} \mathrm{ml}^{-1}$ (IGF-II probe) and $200-400 \mathrm{ng} \mathrm{ml}^{-1}$ (18S RNA probe). The samples were incubated for $10 \mathrm{~min}$ at $85^{\circ} \mathrm{C}$ followed by a further incubation at $55^{\circ} \mathrm{C}$ for $16-20 \mathrm{~h}$. The samples were then treated with $300 \mu$ l RNase digestion buffer (Armstrong and Hogg, 1994) and incubated at $30^{\circ} \mathrm{C}$ for $60 \mathrm{~min}$. The hybridization mixtures were adjusted with SDS to give a final concentration of $0.5 \%$ and digested with $50 \mu \mathrm{g}$ proteinase $\mathrm{K}$ for further $15 \mathrm{~min}$ at $37^{\circ} \mathrm{C}$. The samples were then extracted with phenol:chloroform:isoamyl alcohol (25:24:1), precipitated with ethanol and resuspended in $10 \mu \mathrm{l}$ gel loading buffer $\left(80 \%(\mathrm{v} / \mathrm{v})\right.$ formamide, $10 \mathrm{mmol} \mathrm{EDTA} \mathrm{I}^{-1}, 1 \mathrm{mg}$ xylene 


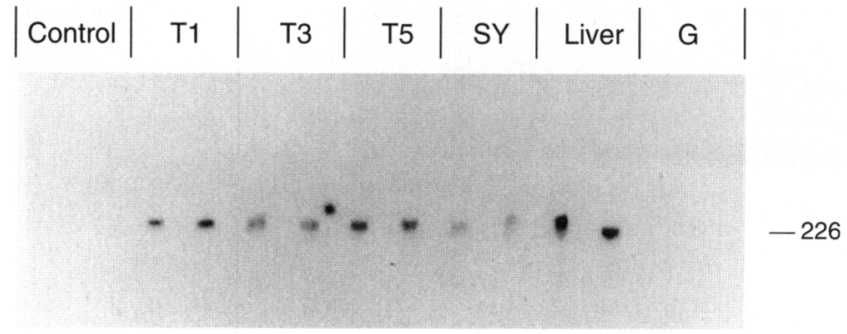

Fig. 1. RNase protection of an insulin-like growth factor I (IGF-I) antisense RNA probe with RNA $(50 \mu \mathrm{g})$ from ovarian follicular and liver tissue of hens. Hybridization was performed at $55^{\circ} \mathrm{C}$ for $16 \mathrm{~h}$ and the RNase-protected probe was visualized after autoradiography for $16 \mathrm{~h} . \mathrm{T} 1, \mathrm{~T} 3, \mathrm{~T} 5$ and SY represent theca tissue from the largest, third largest and fifth largest preovulatory follicles and small yellow $(2-6 \mathrm{~mm})$ follicles, respectively. $G$ represents granulosa tissue from the largest preovulatory follicle. In the control reaction, $50 \mu \mathrm{g}$ of tRNA was used instead of the ovarian or liver RNA. The bars indicate the size of the RNase-protected RNA-RNA hybrids.

cyanol $\mathrm{FF} \mathrm{ml} \mathrm{ml}^{-1}$ and $\mathrm{Img}$ bromophenol blue $\mathrm{ml}^{-1}$ ). After heating to $95^{\circ} \mathrm{C}$ for $5 \mathrm{~min}$, the samples were loaded onto an $8 \%$ polyacrylamide gel containing urea $\left(8 \mathrm{~mol} \mathrm{l}^{-1}\right)$, run down the gel for $4-5 \mathrm{~h}$ at $200 \mathrm{~V}$ and exposed to X-ray film. The validation of the assay is described by Armstrong and Hogg (1994).

Expression of genes encoding IGF-I, IGF-II, IGFr and I8S RNA was measured in the same RNA sample from each tissue from four birds. The results from a representative bird are shown.

\section{Results}

\section{Expression of gene encoding IGF-I}

Expression of the gene encoding IGF-I in follicular tissue collected $3 \mathrm{~h}$ after an ovulation is shown (Fig. 1). The results are representative of four separate experiments performed on four birds, all of which were killed $3 \mathrm{~h}$ after an ovulation. A single RNase-protected band (226 bases) was obtained in all theca preparations. No expression was detected in granulosa cells from F1 follicles. Similar results were obtained with granulosa tissue from F3 and F5 follicles (results not shown). The amount of mRNA encoding IGF-I was greatest in theca
RNA preparations from large preovulatory follicles and lowest in small follicles (2-6 mm in diameter). This difference between large preovulatory follicles and small follicles was observed in all the birds examined. Expression of the gene encoding IGF-I in ovarian tissue was significantly less than it was in liver. Similar results were obtained using tissue collected $2-4 \mathrm{~h}$ before an expected ovulation (results not shown).

\section{Expression of the gene encoding IGF-II}

The sequence of the IGF-II probe showed a $100 \%$ similarity to the corresponding region within the chicken IGF-II cDNA clone (Taylor et al., 1991). The amino acid sequence encoded by the probe and the second coding exon of chicken and human IGF-II are compared (Table 1), with two variant forms of chicken IGF-II (Kallinicos et al., 1990) which differ in the amino acid sequence of their respective $\mathrm{D}$ domains.

RNase-protected fragments of the IGF-II probe were detected after hybridization with theca RNA from follicles at all stages of development (Fig. 2). The results shown here are a representative example of those obtained from four birds killed $3 \mathrm{~h}$ after an expected ovulation. As with IGF-I, no expression of IGF-II was detected in granulosa tissue from F1 follicles. This latter observation was confirmed by reverse transcriptase-PCR using the primers described with RNA from F1, F3 and F5 granulosa tissue (results not shown). Three RNase protected bands were obtained $(98,96$ and 90 bases) with theca RNA from F1, F3 and F5 follicles. In all cases, the 98 base RNA hybrid was the least abundant, and expression in theca tissue from $\mathrm{F} 3$ follicles was greater than that with RNA isolated from F1 or F5 follicles. Small follicles ( $2-6 \mathrm{~mm}$ diameter) produced an additional RNase-protected band of size 66 bases which was never observed with theca RNA from large preovulatory follicles. Similar results were obtained using tissue collected 2-4 h before an ovulation. Overall expression of IGF-II mRNA was higher in thecal tissue from small yellow follicles than in thecal tissue from large preovulatory follicles.

The amounts of the 90,96 and 98 base RNase-protected hybrids in theca tissue from FI and F3 follicles was always greater than that found in theca tissue from F5 follicles. In contrast, the relative amount of the 66 base RNase-protected RNA hybrid and the 90,96 and 98 base RNase-protected hybrids showed considerable variation between batches of small follicles from different birds. In the example shown in

Table 1. A comparison of the amino acid sequence encoded by the second coding exon of chicken insulin-like growth factor II (IGF-II) (cExon 2) and human IGF-II (hExon 2) with two variant forms of chicken IGF-II (cIGF-IIa and cIGF-IIb)

\begin{tabular}{|c|c|c|c|c|c|}
\hline & 3 & 4 & 5 & 6 & 7 \\
\hline & 0 & 0 & 0 & 0 & 0 \\
\hline CExon 2 & \multicolumn{5}{|c|}{ RPVGRNNRRINRGIVEECCFRSCDLALLETYCAKSVKSERDSATSLAGLPALNK } \\
\hline hExon 2 & \multicolumn{5}{|c|}{$--\mathrm{AS}-\mathrm{VS}--\mathrm{S}^{*}-----------------\mathrm{TPA}-----\mathrm{V}-\mathrm{TPPTVL}$ PDNF PR } \\
\hline CIGF-IIa & \multicolumn{5}{|c|}{$-----------^{*}-----------------------$} \\
\hline CIGF-IIb & \multicolumn{5}{|c|}{$----------*^{*}----------------------\mathrm{TPA}---$} \\
\hline
\end{tabular}

Dashes represent conserved residues and asterisks indicate the introduction of gaps in the sequence to optimize the alignment. The numbers refer to the residue number within the mature IGF-II peptide. The region coded for by the RNA probe used in these experiments is underlined. 


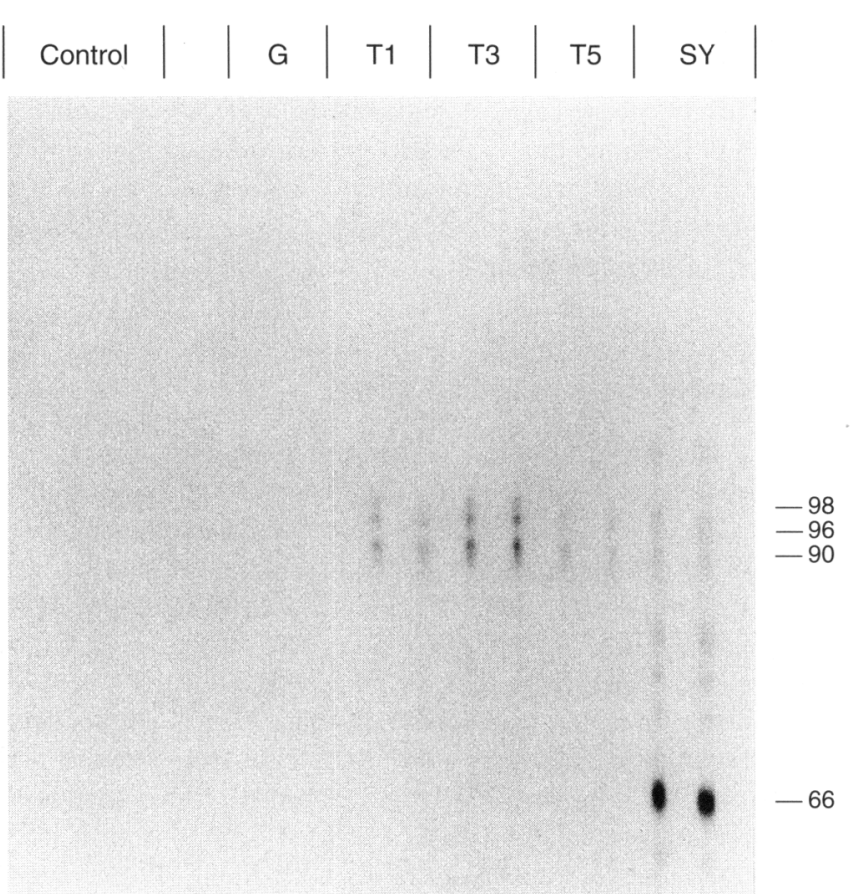

Fig. 2. RNase protection of an insulin-like growth factor II (IGF-II) antisense RNA probe with RNA $(50 \mu \mathrm{g})$ from ovarian follicular tissue of hens. Hybridization was performed at $55^{\circ} \mathrm{C}$ for $16 \mathrm{~h}$ and the RNase-protected probe was visualized after autoradiography for $16 \mathrm{~h}$. T1, T3, T5 and SY represent theca tissue from the largest, third largest and fifth largest preovulatory follicles and small yellow $(2-6 \mathrm{~mm})$ follicles, respectively. $G$ represents granulosa tissue from the largest preovulatory follicle. In the control reaction, $50 \mu \mathrm{g}$ of $\mathrm{tRNA}$ was used instead of the ovarian RNA. The bars indicate the size of the RNase-protected RNA-RNA hybrids.

Fig. 2, the abundance of the 66 base variant was greater than the abundance of the 90,96 and 98 base variants, whereas in other birds the reverse was the case (Fig. 3).

It was concluded from this latter observation that the amount of mRNA encoding IGF-II producing these RNaseprotected bands was changing rapidly during the development of small yellow follicles. Theca expression of the gene encoding IGF-II was therefore analysed in more detail by measuring the changes in the amount of mRNA encoding IGF-II during growth and atresia of small follicles ranging in size from 1 to $6 \mathrm{~mm}$ in diameter (Fig. 3). RNase-protected hybrids of size 98 , 96,90 and 66 were detected using theca RNA from three sizes of small follicles: $1-2 \mathrm{~mm}, 2-4 \mathrm{~mm}$ and $4-6 \mathrm{~mm}$ in diameter. The largest amounts were observed with RNA from small follicles $4-6 \mathrm{~mm}$ in diameter. No expression was detected in follicles 1-2 mm in diameter. The 66-base RNase-protected hybrid was clearly observed with RNA from small follicles 4-6 mm in diameter and barely detectable in follicles $2-4 \mathrm{~mm}$ in diameter. In two of the three RNA preparations isolated from small follicles 4-6 mm in diameter, the amounts of the 98, 96 and 90 base RNase-protected hybrids were greater than the amount of the 66 base hybrids. RNA from small follicles showing the first visible signs of atresia produced low, but detectable, amounts of the 98,96 and 90 base RNase-protected hybrids.

\section{Expression of the gene encoding IGFr}

mRNA encoding IGFr was detected in theca and granulosa tissue from follicles at all stages of development (Fig. 4). A single RNase-protected RNA hybrid (274 bases) was detected for each tissue. Unlike IGF-I and II gene expression, which was not detected in chicken granulosa tissue, the abundance of the mRNA encoding IGFr in granulosa cells was significantly greater than that in theca tissue. Expression of the gene encoding IGFr was also detected in granulosa tissue from F3 and F5 follicles (results not shown). Its concentration was low in theca tissue from small follicles $(2-6 \mathrm{~mm}$ in diameter) and increased as the follicle matured. This was a consistent pattern observed in all birds examined.

\section{5 ribosomal RNA expression}

The human $18 \mathrm{~S}$ ribosomal probe produced two RNaseprotected bands ( 75 and 80 bases). Their intensity was similar in all the tissues examined thus confirming that equal amounts of RNA from each tissue were loaded on to the gel. The results shown (Fig. 5) were obtained using the same RNA samples as for Figs 1, 2 and 4.

\section{Discussion}

The hierarchical arrangement of large preovulatory follicles in the ovary of the domestic fowl and the selection process whereby small follicles are recruited into the follicular hierarchy provides an ideal model system for studying ovarian function. However, although the involvement of gonadotrophins in the control of steroidogenesis and folliculogenesis has been extensively studied in this species (Etches, 1990; Johnson, 1990) there is only limited information on the involvement of growth factors in these processes (Johnson, 1993). The effects of IGF-I on chicken ovarian steroidogenesis and cell proliferation have been described together with limited information on expression of the gene encoding IGF-I (Roberts et al., 1994; Peddie et al., 1993; Onagbesan and Peddie, 1995). The present study was therefore designed to provide further information on the IGF system in the chicken ovary by measuring expression of genes encoding IGF-I, IGF-II and IGFr in theca and granulosa tissue in follicles at different stages of development.

The pattern of expression of genes encoding IGF-I and -II in granulosa and theca tissue of hens is different from that found in mammals. In ovaries, collected either before or after an ovulation, their expression is confined solely to theca tissue, no expression being detected in granulosa cells from the largest preovulatory follicle. An earlier study using PCR (Roberts et al., 1994) demonstrated IGF-I expression in both theca and granulosa tissue. We can offer no explanation for this discrepancy. However, the results presented here indicate that if the gene encoding IGF-I is expressed in granulosa tissue it is below the sensitivity of the RNase protection assay and its expression is significantly less than that in thecal tissue. It is of interest in this respect to note that expression of the gene encoding IGF-II was not detected in granulosa tissue using PCR.

The expression of IGFr in theca and granulosa tissue from those same follicles showed a different pattern from that observed with IGF-I and IGF-II. In this case, expression in 


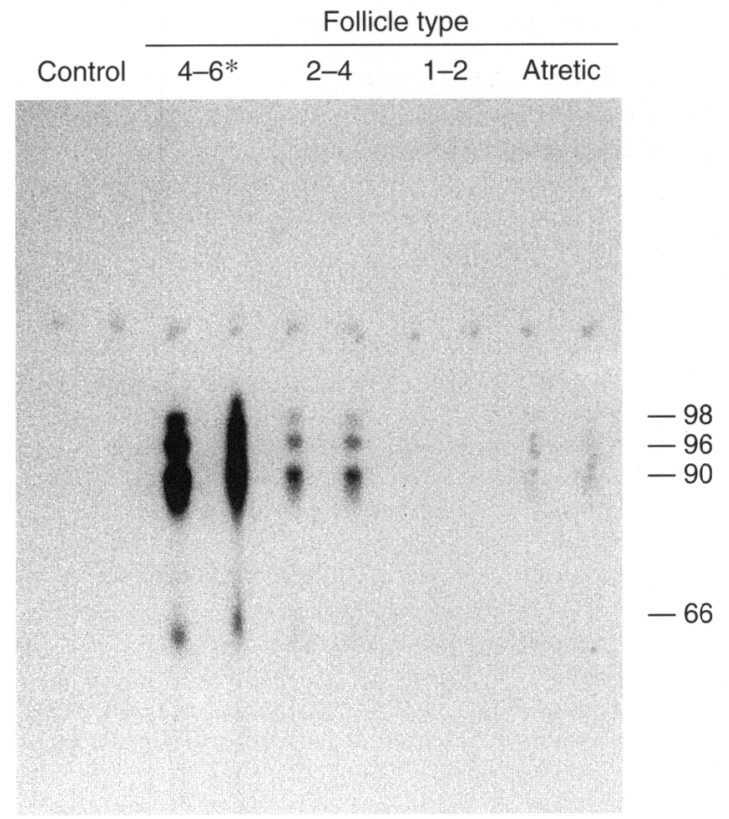

Fig. 3. RNase protection of an insulin-like growth factor II (IGF-II) antisense RNA probe with RNA $(50 \mu \mathrm{g})$ from four classes of small follicles from hens. Hybridization was performed at $55^{\circ} \mathrm{C}$ for $16 \mathrm{~h}$ and the RNase-protected probe was visualized after autoradiography for $16 \mathrm{~h}$. In the control reaction, $50 \mu \mathrm{g}$ of tRNA was used instead of the ovarian RNA. The bars indicate the size of the RNase-protected RNA-RNA hybrids. *Follicle diameter (mm).

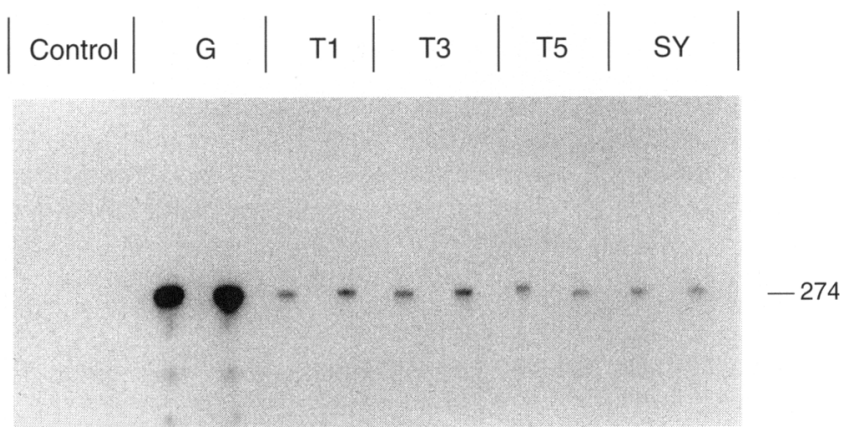

Fig. 4. RNase protection of a type-I insulin-like growth factor receptor (IGFr) antisense RNA probe by RNA $(50 \mu \mathrm{g})$ from ovarian follicular tissue of hens. Hybridization was performed at $55^{\circ} \mathrm{C}$ for $16 \mathrm{~h}$ and the RNase-protected probe was visualized after autoradiography for $16 \mathrm{~h}$. T1, T3, T5 and SY represent theca tissue from the largest, third largest and fifth largest preovulatory follicles and small yellow $(2-6 \mathrm{~mm})$ follicles, respectively. $G$ represents granulosa tissue from the largest preovulatory follicle. In the control reaction, $50 \mu \mathrm{g}$ of $t R N A$ was used instead of the ovarian RNA. The bars indicate the size of the RNase-protected RNA-RNA hybrids.

granulosa tissue was significantly greater than that observed in theca tissue. Hens do not contain a type II IGF receptor (Carnfield and Kornfeld, 1989) and hence both IGF-I and IGF-II must act via the type I IGF receptor. Since IGF-I enhances LH stimulation of granulosa cell proliferation and progesterone production in vitro (Roberts et al., 1994; Onagbesan and Peddie, 1995), the results presented here indicate that theca derived

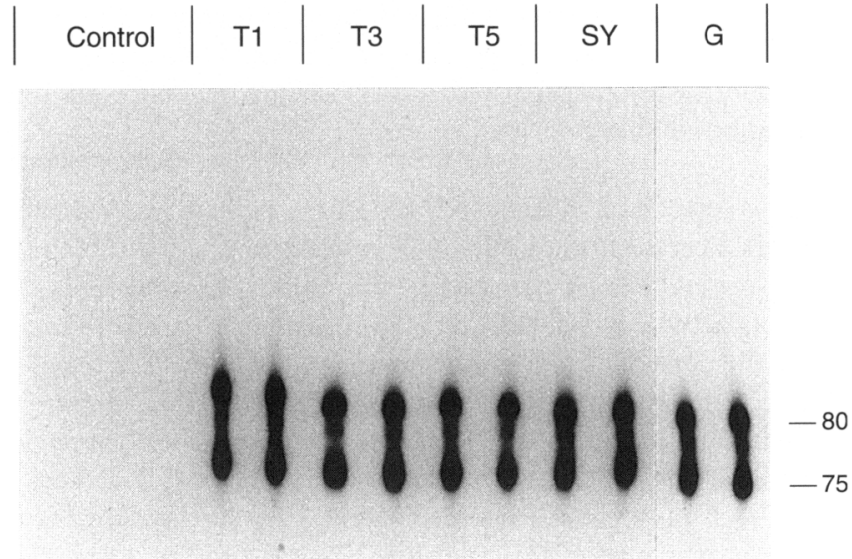

Fig. 5. RNase protection of a human $18 \mathrm{~S}$ RNA probe by RNA ( $5 \mu \mathrm{g}$ ) from ovarian follicular tissue from hens. Hybridization was performed at $55^{\circ} \mathrm{C}$ for $16 \mathrm{~h}$ and the RNase-protected probe was visualized after autoradiography for $16 \mathrm{~h}$. T1, T3, T5 and SY represent theca tissue from the largest, third largest and fifth largest preovulatory follicles and small yellow $(2-6 \mathrm{~mm})$ follicles, respectively. $G$ represents granulosa tissue from the largest preovulatory follicle. In the control reaction, $50 \mu \mathrm{g}$ of tRNA was used instead of the ovarian RNA. The bars indicate the size of the RNase-protected RNA-RNA hybrids.

IGF-I and IGF-II have the potential to control granulosa cell function via paracrine mechanisms.

A precise role for IGF-II in controlling ovarian function has yet to be established, although its expression in ovarian tissue from a number of mammals is now well documented. The results presented here provide indirect evidence of a role for IGF-II in the control of avian ovarian follicular development. The probe used to detect mRNA encoding IGF-II spanned part of the second coding exon of the chicken gene encoding IGF-II that codes for the $\mathrm{C}, \mathrm{A}$ and $\mathrm{D}$ domains and parts of the $\mathrm{B}$ and $E$ domains. The presence of multiple RNase-protected bands in the theca tissue from large preovulatory follicles indicates the possibility of alternate splicing of the mRNA encoding IGF-II over the region spanned by the probe. The results also indicate that the type of mRNA encoding IGF-II transcripts present in theca tissue from small follicles is different from that found in theca tissue from the large preovulatory follicles (presence and absence of a 66 base RNase-protected fragment in small and large preovulatory follicles, respectively). The physiological significance of this difference is unknown. However, comparison of the sequence of two variant forms of chicken IGF-II (Kallinicos et al., 1990) with the amino acid sequence of the second coding exon of chicken and human IGF-II indicates that the differences could arise from the presence or absence of sequences coding for a TPA sequence (residues 69-71) in the chicken variants. The RNase-protected bands observed in theca tissue from F1, F3 and F5 follicles are likely to have arisen from mRNA coding for the variant lacking the TPA sequence resulting in the production of RNase protected bands of size 98,96 and 90 . Hybridization of the IGF-II probe with mRNA encoding the variant containing the TPA sequence would generate a RNase-protected band of 66 bases as observed with the RNA from theca tissue from small follicles. Whether the two variants arise from alternative splicing of the IGF-II mRNA primary transcript or from the presence of two closely related 
but distinct genes, awaits further study. However, the exact matching of the actual size of the 66-base RNase-protected fragment with its predicted size is strong evidence for the presence of the two variant forms of IGF-II in the avian ovary.

It is concluded that, since the 66-base variant was detected in only a proportion of small yellow follicles, the IGF-II variant is expressed only for a limited period of follicular development. Its appearance, in follicles $4-6 \mathrm{~mm}$ in diameter, coincides both with the period during which small yellow follicles are selected for recruitment into the follicular hierarchy and with the time at which their granulosa cells become steroidogenically competent (Tilly et al., 1991). We suggest that the IGF-II variant is expressed only in follicles at the time they are recruited into the follicular hierarchy; if the IGF-II variant is not expressed, the follicles become atretic. If this hypothesis proves to be correct, then the IGF-II variant would be a major determinant of follicular fate.

In conclusion, the results of this study indicate that expression of the genes encoding IGF-I and -II is confined to the theca tissue of the large preovulatory follicles. The relatively high expression of IGFr in granulosa tissue at this time indicates that IGFs produced in theca tissue control granulosa function by paracrine mechanisms. The results also support a major role for IGF-II in the intraovarian control of ovarian function.

\section{References}

Adashi EY and Roban RM (1992) Intraovarian regulation: peptidergic signalling systems Trends in Endocrinology and Metabolism 3 243-248

Adashi EY, Resnick CE, D'Ercole AJ, Svobada ME and Van Wyk JJ (1985) Insulin-like growth factors as intraovarian regulators of granulosa cell growth and function Endocrine Reviews 6 400-420

Adashi EY, Resnick CE, Hurwitz A, Zicciarelli E, Hernandez ER, Roberts CT, LeRoith D and Rosenfeld R (1992) The intraovarian IGF system Growth Regulation 2 10-15

Armstrong DG (1994) The effect of LH, FSH and pregnant mares' serum gonadotrophin on ornithine decarboxylase activity in theca and granulosa tissue during follicular growth and atresia in laying hens (Gallus domesticus) Journal of Reproduction and Fertility 100 273-278

Armstrong DG and Hogg CO (1992) The expression of a putative insulin-like growth factor-I receptor gene in the ovary of the developing chick Journal of Molecular Endocrinology 8 193-201

Armstrong DG and Hogg CO (1994) Type-I insulin-like growth factor receptor gene expression in the chick. Developmental changes and the effect of selection for increased growth on the amount of receptor mRNA Journal of Molecular Endocrinology 12 3-12

Baker J, Liu J, Robertson EJ and Efstratiadis A (1993) Role of insulin-like growth factors in embryonic and postnatal growth Cell 75 73-82

Carnfield WM and Kornfeld S (1989) The chicken mannose-6-phosphate receptor lacks the high affinity binding site for insulin-like growth factor II Journal of Biological Chemistry 264 7100-7103

Daughaday WH and Rotwein P (1989) Insulin-like growth factors I and II. Peptide, messenger ribonucleic acid and gene structure, serum and tissue concentrations Endocrine Reviews 10 68-91

Decuypere E, Huybrechts IM, Kuhn ER, Tixier-Boichard M and Merat P (I991) Physiological alterations associated with chicken sex-linked dwarfing gene Critical Reviews in Poultry Biology 3 191-221

Dor J, Ben-Shlomo I, Lunenfeld B, Pariente C, Levron D, Karasik A, Seppala M and Mashiach S (1992) Insulin-like growth factor-I (IGF-I) may not be essential for ovarian follicular development: evidence from an IGF-I deficiency Journal of Clinical Endocrinology and Metabolism 74 539-542

El-Roeiy A, Chen X, Roberts VJ, LeRoith D, Roberts CT, Jr and Yen SSC (1993) Expression of insulin-like growth factor-I (IGF-I) and IGF-II and the IGF-I,
IGF-II and insulin receptor genes and localization of the gene products in the human ovary Journal of Clinical Endocrinology and Metabolism 77 $1411-1418$

Etches RJ (1990) The ovulatory cycle of the hen Critical Reviews in Poultry Biology 2 293-318

Fawcett DH and Bulfield G (1990) Molecular cloning, sequence analysis and expression of putative chicken insulin-like growth factor I cDNA's Journal of Molecular Endocrinology 4 201-211

Gilbert AB, Perry MM, Waddington D and Hardie MA (1983) The role of atresia in establishing the follicular hierarchy in the ovary of the domestic hen (Gallus domesticus) Journal of Reproduction and Fertility 69 221-227

Giudice LC (1992) Insulin-like growth factors and ovarian development Endocrine Reviews 13 641-669

Hernandez ER, Roberts CH, Hurwitz A, LeRoith D and Adashi EY (1990) Rat ovarian insulin-like growth factor-II gene expression is theca interstitial cell exclusive: hormonal regulation and receptor distribution Endocrinology 127 $3249-3252$

Hernandez ER, Hurwitz A, Vera A, Pellicer A, Adashi EY, LeRoith and Roberts CT, Jr (1992) Expression of genes encoding the insulin-like growth factors and their receptors in the human ovary Journal of Clinical Endocrinotogy and Metabolism $\mathbf{7 4} 419-425$

Hsu CJ and Hammond JM (1987) Gonadotropins and estradiol stimulate immunoreactive insulin-like growth factor-1 production by porcine granulosa cells in vitro Endocrinology 121 1343-1348

Hutchinson LA, Findley JK and Herrington AC (1988) Growth hormone and insulin-like growth factor-1 accelerate PMSG induced differentiation of granulosa cells Molecular and Cellular Endocrinology 55 61-69

Johnson AL (1990) Steroidogenesis and the actions of steroids in the hen's ovary Critical Reviews in Poultry Biology 2 319-346

Johnson AL (1993) Regulation of follicle differentiation by gonadotropins and growth factors Poultry Science $\mathbf{7 2} 867-873$

Kallinicos NC, Wallace JC, Francis GC and Ballard FJ (1990) Chemical and biological characterization of chicken insulin-like growth factor-II Journal of Endocrinology 124 89-97

Laron Z, Perzelan A and Karp M (1966) Pituitary dwarfism and high levels of growth hormone Israeli Journal of Medical Science 2 152-155

Liu J, Baker J, Perkins AS, Robertson EJ and Efstratiadis A (1993) Mice carrying null mutations of the genes encoding insulin-like growth factor I (IGF-I) and type I IGF receptor (IGFIr) Cell 75 59-72

Mondschein JS, Canning SF, Miller DQ and Hammond JM (1989) Insulin-like growth factors (IGFs) as autocrine/paracrine regulators of granulosa cell differentiation and growth: studies with a neutralizing monoclonal antibody to IGF-1 Biology of Reproduction 41 79-85

Oliver JE, Aitman TJ, Powell JF, Wilson CA and Clayton RN (1989) Insulin-like growth factor-I expression in the rat ovary is confined to granulosa cells of developing follicles Endocrinology 124 2671-2679

Onagbesan OM and Peddie MJ (1995) Effects of insulin-like growth factor I and interactions with transforming growth factor $\alpha$ and LH on proliferation of chicken granulosa cells and production of progesterone in culture Journal of Reproduction and Fertility 104 259-265

Peddie MJ, Onagbesan OM and Woolveridge I (1993) The role of epidermal growth factor and other factors in the paracrine and autocrine control of ovarian follicular development in the domestic hen. In Avian Endocrinology pp 321-330 Ed. PJ Sharp. Journal of Endocrinology Ltd, Bristol

Rechler MM and Nissley SP (1985) The nature and regulation of the receptors for insulin-like growth factors Annual Review of Physiology $\mathbf{4 7}$ 425-442

Roberts RD, Sharp PJ, Burt DW and Goddard C (1994) Insulin-like growth factor-I in the ovary of the laying hen: gene expression and biological actions on granulosa and theca cells General and Comparative Endocrinology $93327-336$

Rotwein P (1991) Structure, evolution, expression and regulation of insulin-like growth factors I and II Growth Factors 5 3-18

Taylor ER, Seleiro EAP and Brickell PM (1991) Identification of antisense transcripts of the chicken insulin-like growth factor II gene. Journal of Molecular Endocrinology 12 193-201

Tilly JL, Kowalski KI and Johnson AL (1991) Stage of follicular development associated with the initiation of steroidogenic competence in avian granulosa cells Biology of Reproduction 44 305-314 